\title{
Correction to: Inverse heat transfer analysis in detecting tissue optical properties using laser
}

\section{Khalid Salem Shibib $^{1}$ (D) Dhuha Shaker ${ }^{1}$}

Published online: 28 May 2019

(C) Springer-Verlag London Ltd., part of Springer Nature 2019

\section{Correction to: Lasers in Medical Science} https://doi.org/10.1007/s10103-019-02767-8

The published online version contains a mistake in equation 2c. The correct equation is shown below:

$k \partial T / \partial x=h\left(T-T_{\infty}\right) \quad$ at $\mathrm{x}=0, \mathrm{~L}$

The original article has been corrected.

Publisher's note Springer Nature remains neutral with regard to jurisdictional claims in published maps and institutional affiliations.

The online version of the original article can be found at https://oi.org/ 10.1007/s10103-019-02767-8

\footnotetext{
Khalid Salem Shibib

profkhalidsalem@gmail.com

1 Laser and Optoelectronics Engineering Department, University of Technology, Baghdad, Iraq
} 